\title{
KEMASAN ULANG DAN DISPLAY PRODUK MAKANAN RINGAN KELURAHAN KERANGGAN
}

\author{
James Darmawan', Ardi Gunawan ${ }^{2}$, Hilmi Fabeta ${ }^{3}$ \\ Institut Sains dan Teknologi Pradita ${ }^{1,2,3}$ \\ 1 james.darmawan@pradita.ac.id, ${ }^{2}$ ardi.gunawan@ pradita.ac.id, ${ }^{3}$ hilmi.fabeta@ pradita.ac.id
}

\begin{abstract}
Abstrak
Seiring meningkatnya persaingan dagang pada zaman sekarang, produk makanan ringan produksi para ibu rumah tangga Kelurahan Kranggan - Serpong Tangerang Selatan, membutuhkan desain kemasan dan display produk makanan ringan yang memiliki daya saing dan daya jual. Dengan adanya kerjasama institusi dengan kelurahan ini, tim penulis membuat penelitian literatur dan observasi dengan jenis dan desain kemasan makanan ringan khas daerah, hasil penelitian ini dijadikan referensi untuk perhitungan biaya untuk menentukan jenis kemasan yang sesuai. Kemudian tim penulis melangkah dari proses koordinasi antar instansi, survei lapangan, analisis data hasil survei, pembuatan desain kemasan ulang, pemilihan desain kemasan, persiapan display produk makanan ringan, dan smapai pada proses tes pasar dan kerjasama pada kantin kampus. Hal ini adalah peluang untuk memberikan bantuan layanan desain. Tim penulis berharap memiliki peluang yang sama dan / atau serupa dalam kegiatan penelitian selanjutnya ini adalah peluang luar biasa untuk memberikan bantuan layanan desain.
\end{abstract}

Kata Kunci: Kemasan Ulang, Display produk, Produk Makanan Ringan, Kelurahan Keranggan.

\section{PENDAHULUAN}

Program Studi Desain Komunikasi Visual (DKV) Institut Sains dan Teknologi Pradita dalam hal ini ingin memberikan kontribusi dalam bentuk kemasan produk makanan ringan makanan ringan desa binaan Kranggan, Maka dari itu Prodi DKV akan memberikan pelatihan kemandirian pertimbangkan dari pengalaman Koperasi Sejahtera Bersama (KSU) Cipta Boga yang sudah memiliki supermaket, sehingga KSU ini sudah memiliki pengalaman dalam penjualan dan pengembangan merek [1] untuk produksi para ibu rumah tangga Kelurahan Keranggan - Serpong Tangerang Selatan, dalam meningkatkan nilai ekonomi produk-produk makanan ringan melalui peningkatan mutu desain kemasan. Usaha Mikro, Kecil dan Menengah (UMKM) memiliki peranan yang sangat penting bagi Kelurahan Keranggan. Kelompok UKMKM di Kelurahan Keranggan merupakan unit usaha bersama yang dibuat oleh para ibu rumah tangga di kelurahan tersebut melalui usaha pembuatan makanan ringan.

Menurut Catharine Fishel, ada upaya yang baik dalam menjual dengan kemasan tersebut untuk memberi nuansa budaya yang kental ${ }^{[2]}$, selama ini kemasan dari produk makanan ringan tersebut hanya menggunakan plastik tanpa identitas, hal tersebut yang membuat produk makanan ringan mereka tidak dikenal masyarakat. Kemasan tidak menarik dan tidak ada standar dari kemasan yang digunakan. Padahal produk-produk tersebut seringkali digunakan sebagai ciri khas produk makanan ringan Kelurahan Keranggan, dan menurut Resnick [3], upaya kemasan ulang ini dapat saja dilakukan dengan membuat permainan kata-kata visual di setiap kemasan, tujuannya adalah untuk menciptakan pemahaman melalui perbandingan visual di setiap variasi. Pemasaran produk-produk yang ada juga terbatas di wilayah UMKM. Dari masalah yang ada, solusi yang ditawarkan adalah menyediakan sosialisasi kemasan produk makanan ringan dan juga

Teknologi Informasi dan Komunikasi 73 
untuk kepengurusan kerjasama penjualan untuk produk makanan ringan ini.

Dengan solusi yang ditawarkan, UMKM diharapkan dapat membuat kemasannya sendiri serta melakukan pemasaran produk makanan ringan melalui media online untuk menaikkan penjualan produk makanan ringan UMKM Kelurahan Keranggan. Tim penulis juga mempertimbangkan desain kemasan dan display dalam dihasilkan dari hierarki visual untuk mengatur semua elemen kemasan dan informasi etis ${ }^{[4]}$. Walaupun secara keseluruhan biaya produksi jatuh lebih mahal, khususnya dalam investasi merek; namun bila hal ini menigkatkan penjualan maka tetap tidak menghalangi pengubahan kemasan dan displau produk makanan ringan ini ${ }^{[5]}$.

Adapun tujuan dari kegiatan Kemasan Ulang

Dan Display Produk Makanan Ringan Kelurahan Keranggan; adalah sebagai berikut:

1. Mengaplikasikan keilmuan dan keahlian yang dimiliki oleh program studi Desain Komunikasi Visual kepada masyarakat melalui pembinaan industri rumah tangga terpadu di Keranggan untuk produk makanan ringan.

2. Mengedukasi masyarakat melalui sosialisasi desain kemasan produk makanan ringan.

3. Membangun karakter dan membina masyarakat agar dapat meningkatkan ekonomi masyarakat setempat.

Bentuk kegiatan pengabdian kepada masyarakat berupa penyuluhan yang dilakukan kepada masyarakat pelaku home industry di RT012 dan RT013. Penyuluhan ini dilakukan dari rumah ke rumah masyarakat. Kegiatan penyuluhan ini dilakukan dengan cara mempresentasikan contohcontoh desain kemasan yang dapat diaplikasikan kepada produk makanan ringan, yang meliputi detail dari bentuk visual, material kemasan yang dapat dipakai, anggaran biaya yang dibutuhkan dan nilai ekonomi yang dapat dihasilkan.

\section{METODE}

Demikian langkah-langkah sistematis yang dilakukan program studi Desain Komunikasi Visual, Institut Sains dan Teknologi Pradita dalam kegiatan pengabdian masyarakat Kemasan Ulang Dan
Display Produk Makanan Ringan Kelurahan Keranggan. Program studi Desain Komunikasi Visual melakukan 6 (enam) tahapan dalam proses kegiatan ini; yaitu dijelaskan lebih lanjut oleh tabel berikut ini:

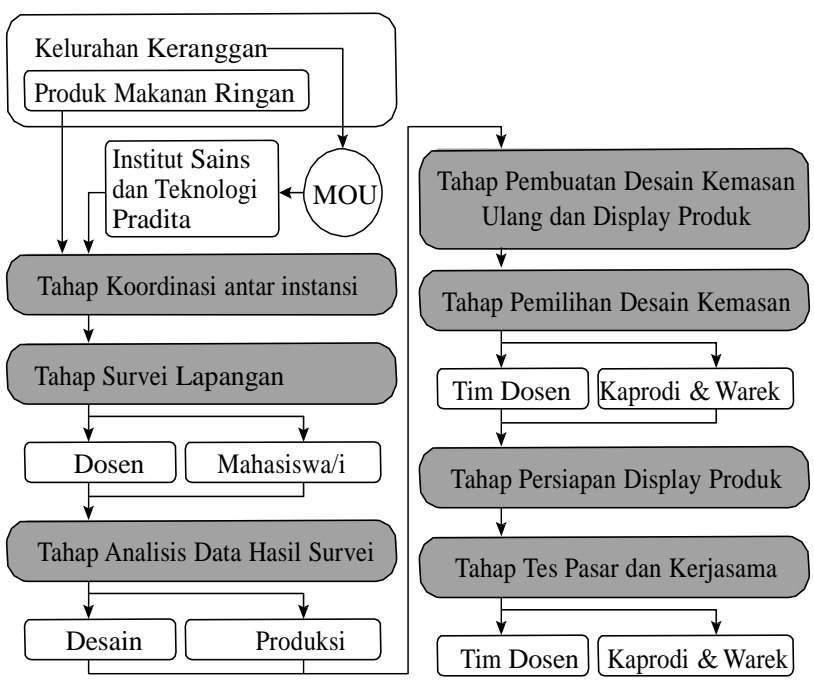

Tabel 1. Metode penulisan yang dilakukan.

Awalnya tahap Koordinasi antar instansi; dilakukan antara Kelurahan Keranggan dan Institut Sains dan Teknologi Pradita untuk mengetahui pemetaan industri rumah tangga Kelurahan Keranggan yang fokus pada makanan ringan.

Tahap Survei Lapangan; dilakukan untuk menidentifikasi idustri rumah tangga makanan ringan yang ada di Kelurahan Keranggan. Kegiatan yang dilakukan pada survey lapangan meliputi observasi produk dan data warga produsen produk makanan ringan.

Dilanjutkan tahap Analisis Data Hasil Survei; dilakukan dengan menyusun tahap-tahap desain kemasan makanan ringan meliputi: survey lokasi pembuatan makanan ringan, pembuatan desain kemasan makanan ringan yang meliputi sketsa, perancangan desain, produksi cetak, dan juga proses dokumentasi serta pelaporan.

Tahap Pembuatan Desain Kemasan Ulang; dilakukan dengan menjahitkannya dengan mata perkuliahan Advertising yang sedang membahas tentang kemasan dan strategi visualnya.

Tahap selanjutnya adalah Pemilihan Desain Kemasan; dilakukan dua tahap, pertama dengan

Teknologi Informasi dan Komunikasi 74 
dosen pengajar mata kuliah terkait, kemudai dengan kepala program studi dan wakil rektor bagian akademik yang telah lama menjalin kerjasama bersama kelurahan Keranggan.

Tahap Persiapan Display Produk; dilakukan dengan merancang struktur display sagar kuat menahan beban produk makanan ringan, dengan pertimbangan ruang untuk mendisplay produk makanan ringan dengan desain iklan banner pada setiap sisi dari segmentasinya.

Terakhir tahap Tes Pasar dan Kerjasama; dilakukan dengan pihak para produsen ibu rumah tangga kelurahan Keranggan, dan di tes jual pada tawaran buka stand bersama dengan Akademi Bambu Nusantara $(\mathrm{ABN})$ dalam acara pemerintah kota Tangerang Selatan dalam tema spesial Galeri Ethnik Nusantara yang di selenggarakan di World Trade Center Serpong. Kemudian dilanjutkan dengan kerjasama pihak kantin institusi dibawah Koperasi Summarecon.

\section{HASIL DAN PEMBAHASAN}

Terdapat 6 (enam) tahap yang dilakukan tim penulis dalam emalkukan kegiatan Kemasan Ulang dan Display Produk Makanan Ringan Kelurahan Keranggan; yang antara lain adalah sebagai berikut:

\section{Tahap Koordinasi Antar Instansi}

Pada tahap ini tim penulis melakukan kelanjutan dari perjanjian antara Institut Sains dan Teknologi Pradita dengan Kelurahan Keranggan untuk membantu produksi ibu rumah tangga, khususnya untuk produk makanan ringan. Dalam hal ini program studi Desain Komunikasi Visual melakukan program pembuatan kemasan ulang dan disply produk makanan ringan untuk meningkatkan penjualan dengan pendekatan imaji strata ekonomi yang lebih tinggi.

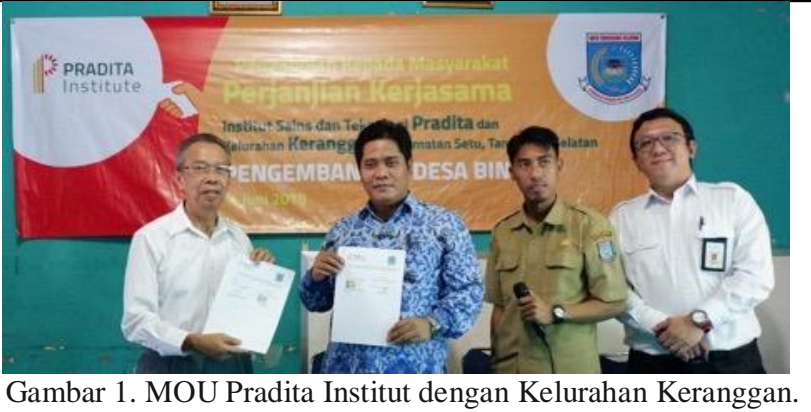

Sebelum penulisan ini, program studi Desain Komunikasi Visual juga sudah melakukan simulasi pada kemasan ulang dengan keilmuan para pengajar program studi ${ }^{[6]}$, sehingga para penulisan kali ini tim penulis tidak membahas proses desain secara mendetail, namun lebih kepada keseluruhan proses kegiatan Kemasan Ulang Dan Display Produk Makanan Ringan Kelurahan Keranggan.

Pada penulisan kali ini tim penulis menyimpulkan bahwa peranan desain komunikasi visual tidak hanya berperan dalam memvisualisasi kemasan dan display, tetapi menjadi konsultan yang meningkatkan persaingan dagang melalui visual yang hendak ditampilkan. Hal ini tidaklah mudah karena perlu pendekatan dengan para produsen ibu rumah tangga Kelurahan Keranggan untuk menyampaikan maksud dan tujuan kegiatan ini tanpa memberikan bayangan yang merepotkan atau mengubah proses produksi yang selama ini sudah mereka lakukan sehari-hari.

\section{Tahap Survei Lapangan}

Pada tahap ini tim penulis kembali melakukan survei lapangan terhadap produsen ibu rumah tangga Kelurahan Keranggan. Hal ini dilakukan bersama semua mahasiswa/i yang terkait mata kuliah Advertising, sehingga semua merasakan kondisi dan situasi yang dihadapi langsung oleh produsen. 


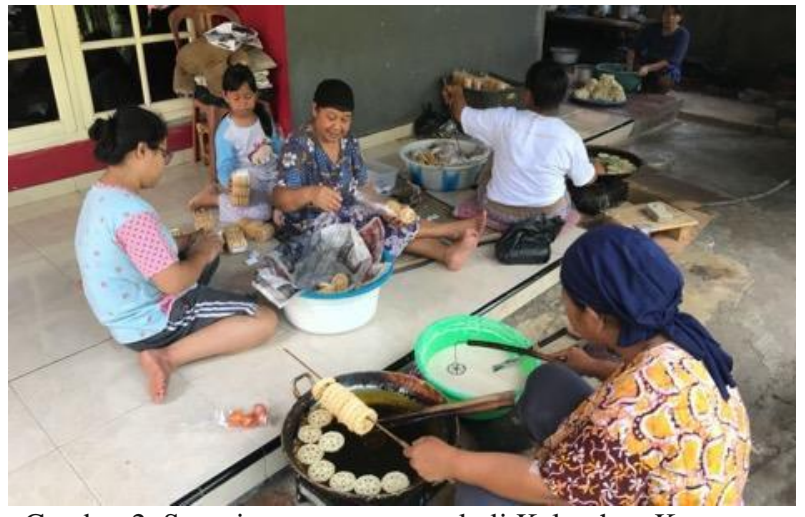

Gambar 2. Survei suasana memasak di Kelurahan Keranggan.

Selain itu juga para mahasiswa/i banyak yang melakukan perbincangan dengan para ibu rumah tangga Kelurahan Keranggan sehingga terjalin komunikasi yang lebih dalam daripada sekedar komunikasi antara penjual dan pembeli.

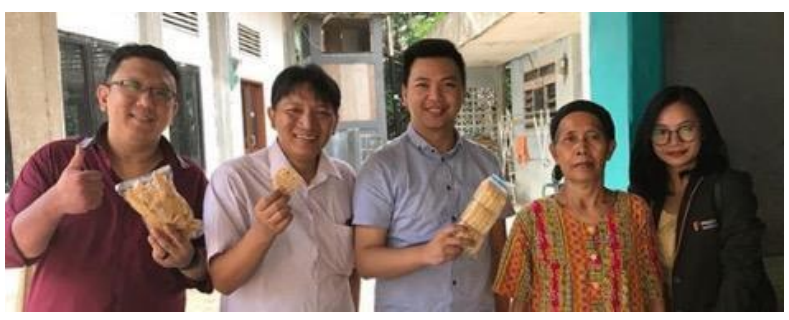

Gambar 3. Survei tim dosen di Kelurahan Keranggan.

Sehingga melalui tahap survei ini, kembali tim penulis dapat menyimpulkan bahwa pentingnya sebuah komunikasi bahkan non-formal dapat membangun ikatan emosional yang mempermudah bagi desainer komunikasi visual untuk berkarya lebih matang dan lebih sesuai dengan kebutuhan dan keadaan yang riil.

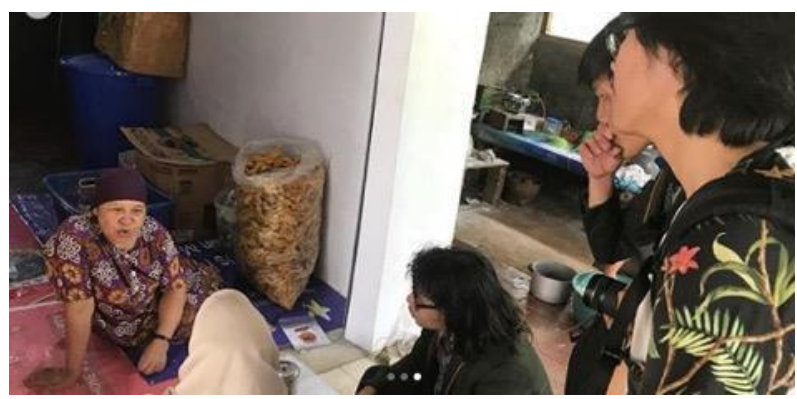

Gambar 4. Survei para mahasiswa/i di Kelurahan Keranggan.
Hal ini juga membuat para dosen pengampu mata kuliah advertising untuk lebih mudah dalam memberikan pengarahan yang sesuai dan lebih membumi; dalam menyampaikan harapan apa yang hendak dibangun oleh hasil komunikasi visual pada kemasan ulang dan display produk nanti.

\section{Tahap Analisis Data Hasil Survei}

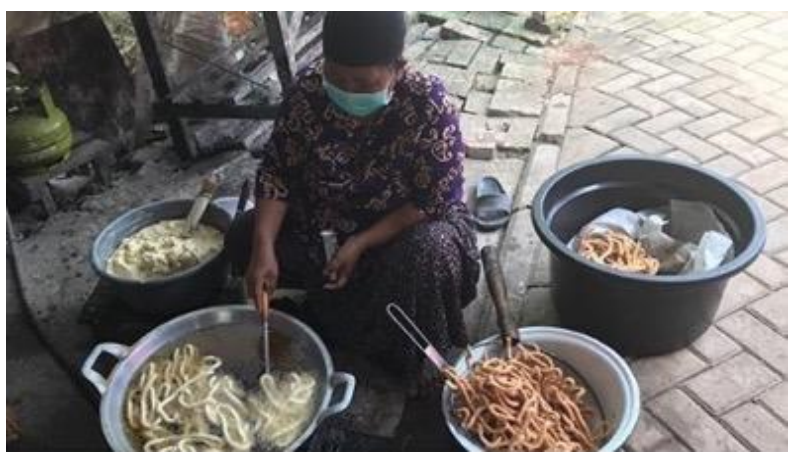

Gambar 5. Salah satu produsen di Kelurahan Keranggan.

Pada tahap ini tim penulis melakukan pendataan hasil survei yang meliputi: data ibu rumah tangga mana yang memiliki tingkat kebersihan yang baik, data ibu rumah tangga mana yang memiliki banyak variasi pada produk makanan ringan yang dihasilkan, serta kemasan apa yang dipakai oleh produsen sehingga menentukan harga jual dan kebutuhan kemasan ulang.

\begin{tabular}{|l|l|l|l|}
\hline Produsen & Higienis & Variasi & Kemasan \\
\hline Bu Lulu & $\begin{array}{l}\text { Masak } \\
\text { di } \\
\text { halaman }\end{array}$ & $\begin{array}{l}\text { Tidak } \\
\text { ada } \\
\text { singkong }\end{array}$ & $\begin{array}{l}\text { Plastik } \\
\text { tidak } \\
\text { Bermerek }\end{array}$ \\
\hline Bu Lis & $\begin{array}{l}\text { Masak } \\
\text { halaman }\end{array}$ & Lengkap & $\begin{array}{l}\text { Plastik } \\
\text { tidak } \\
\text { Bermerek }\end{array}$ \\
\hline Bu Supiyah & $\begin{array}{l}\text { Masak } \\
\text { di dapur }\end{array}$ & Lengkap & $\begin{array}{l}\text { Plastik } \\
\text { tidak } \\
\text { Bermerek }\end{array}$ \\
\hline Bu Ami & $\begin{array}{l}\text { Masak } \\
\text { di } \\
\text { halaman }\end{array}$ & Lengkap & $\begin{array}{l}\text { Plastik } \\
\text { tidak } \\
\text { Bermerek }\end{array}$ \\
\hline Bu Marni & $\begin{array}{l}\text { Masak } \\
\text { di dapur }\end{array}$ & $\begin{array}{l}\text { Tidak } \\
\text { ada } \\
\text { pisang }\end{array}$ & $\begin{array}{l}\text { Plastik } \\
\text { tidak } \\
\text { Bermerek }\end{array}$ \\
\hline
\end{tabular}

Tabel 2. Daftar produsen Kelurahan Keranggan.

Teknologi Informasi dan Komunikasi 76 
Sehingga tim penulis menyimpulkan bahwa beberapa keuntungan dapat diperoleh apabila produsen memiliki banyak variasi dalam memproduksi produk makanan ringan ini, namun faktor higienis menjadi keutamaan dalam pemilihan produsen. Selain itu kemasan yang digunakan ternyata sama, yaitu plastik bening dengan staples dijepit pada kertas kecil, tapai ada merek sama sekali. Pada hasil survei kali ini tim penulis mendapatkan kemungkinan terbesar adalah bekerjasama dengan produsen Ibu Supiyah.

\section{Tahap Pembuatan Desain Kemasan Ulang}

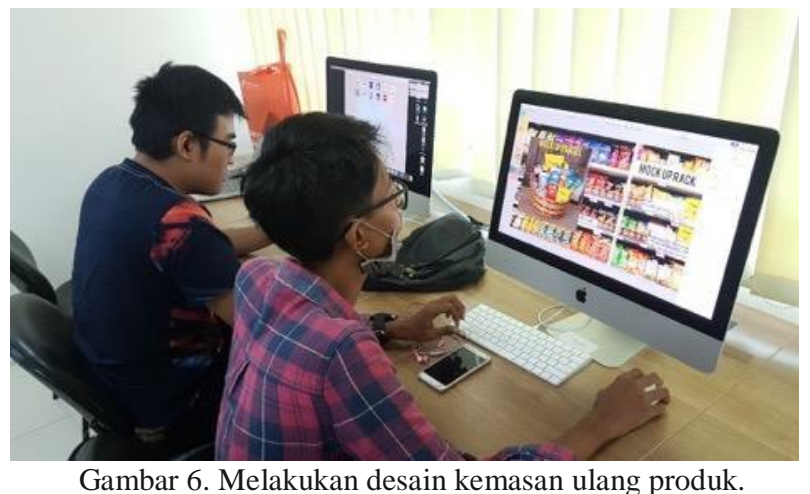

Pada tahap ini tim penulis melakukan penjahitan dengan mata kuliah advertising, dimana terdapat salah satu dosen advertising juga merupakan tim penulis. Dari hal ini didapati bahwa pendekatan hasil survei dapat digunakan dengan maksimal dengan memutsar kembali video dokumentasi. Sehingga detail dari nuasa wawancara survey kembali terulang khususnya secara emosi.

Dari hasil dan progres pembuatan desain kemasan luang ini tim penulis menyimpulkan bahwa proses survei menentukan hasil desain yang dibuat. Khususnya dalam menangkap emosi produsen, para mahasiswa/i menangkap karakter apa yang dibawakan oleh ibu rumah tangga terkait.

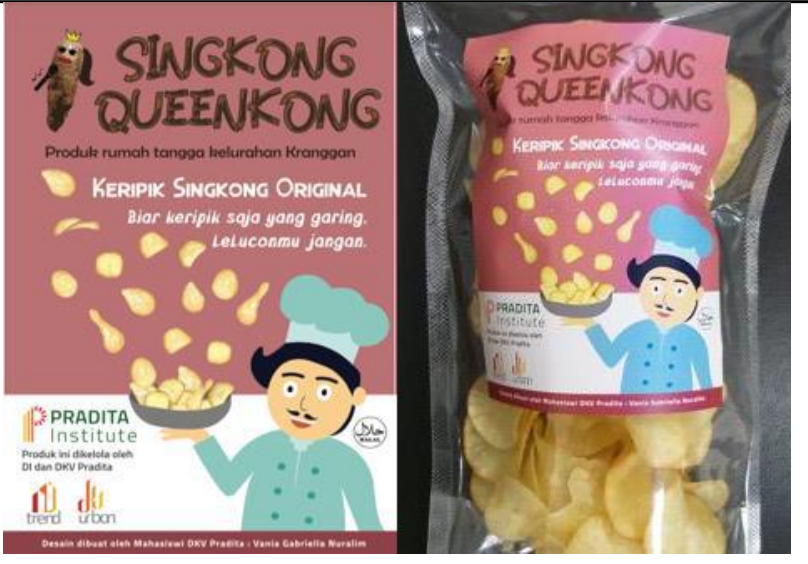

Gambar 7. Pendekatan desain kemasan keripik singkong.

Misalnya dalam membahas produk keripik singkong; Ibu Supiyah menceritakan anaknya yang menyukai singkong sejak kecil; laksana anak singkong, untuk itu desain mengacu pada komik dengan maskot chef kecil yang berkumis.

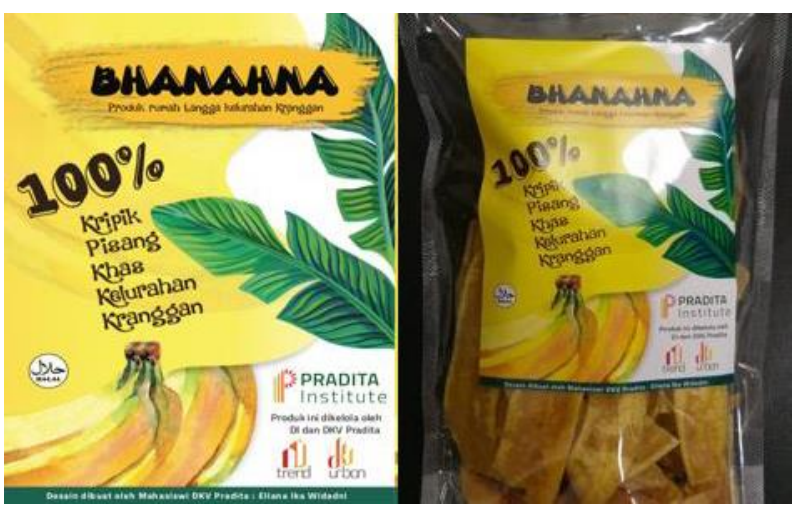

Gambar 8. Pendekatan desain kemasan keripik singkong.

Sedangkan pada saat membahas produk keripik pisang diceritakan bahwa Ibu Supiyah merasa produk ini merupakan produk yang paling laku, sehingga suatu hari nanti diharapkan produk ini dapat dijual ke manca negara; untuk itu pun desain yang dihasilkan mahasiswa/i lebih serius dan profesional.

Berbeda dengan ketika membahas produk keripik kembang goyang, dimana produk makanan ringan jenis ini adalah makanan ringan yang paling dicari akum muda yang tertarik dengan bentuknya yang unik, serta cara pembuatannya yang butuh goyangan sehingga adonan dapat lepas tergoreng dengan indah.

\begin{tabular}{l|l} 
Teknologi Informasi dan Komunikasi & 77
\end{tabular} 


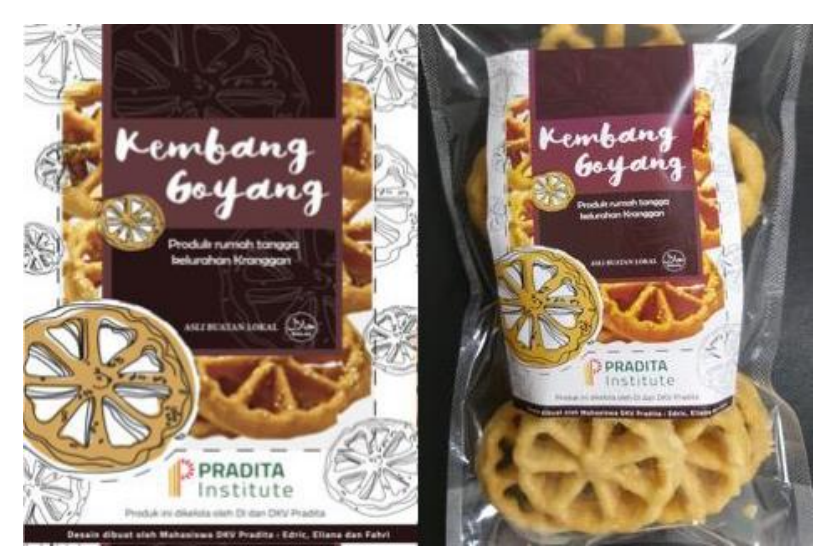

Gambar 9. Pendekatan desain kemasan kembang goyang.

Semua desain kemasan ini diberikan nama mahasiswa/i sebagai desainernya. Hal ini menjadi portofolio bagi mahasiswa/i yang hasil tugasnya benar-benar dapat terimplementasi dengan produk makanan ringan Kelurahan Keranggan secara riil.

\section{Tahap Pemilihan Desain Kemasan}

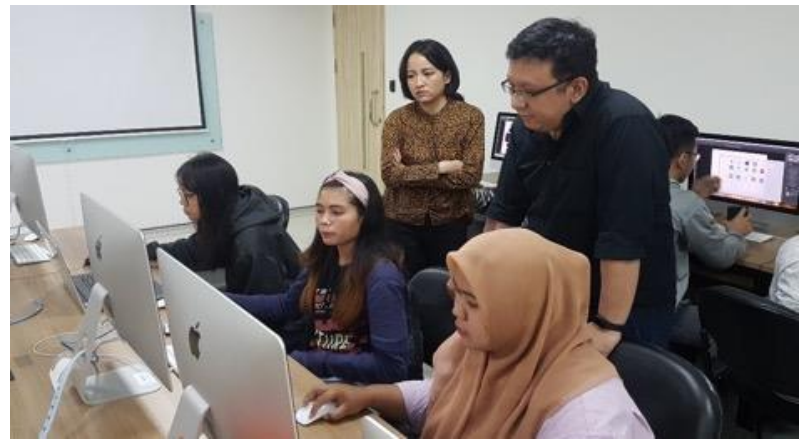

Gambar 10. Asistensi kemasan ulang produk makanan ringan.

Pada tahap ini tim penulis melakukan pemilihan dari karya terbaik. Terdapat 2 (dua) sesi dalam proses pemilihan ini, antara lain dengan dosen pengampu mata kuliah Advertising, yang berupa asistensi agar semua variasi desain kemasan ulang dapat dipaparkan pada pemilihan selanjutnya.

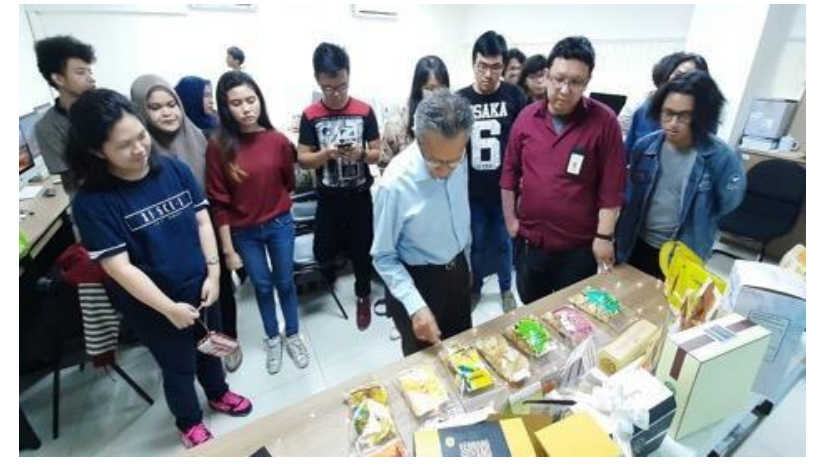

Gambar 11. Pemilihan final oleh Prof. Harianto Hardjasaputra.

Setelah selesai pemilihan pertama ini, tim penulis melakukan proses pemilihan berikutnya dengan kepala program studi dan wakil rektor untuk mendapatkan pilihan final dan proses revisi terakhir sebelum desain siap masuk produksi secara masal.

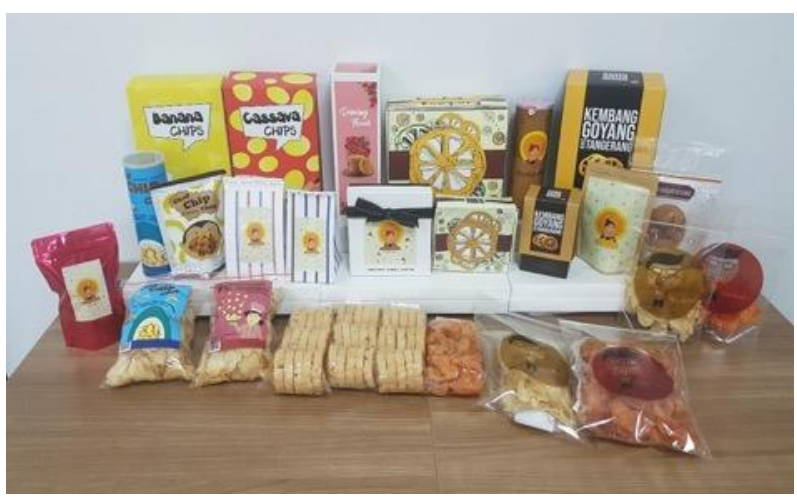

Gambar 12. Hasil variasi desain kemasan ulang produk.

Dari proses pemilihan final ini, dengan pertimbangan nilai estetika, nilai nuansa produk makanan ringan dari keselarasan wawancara, dan nilai pendekatan yang saling berbeda untuk calon konsumen yang berbeda pula, maka hasil desain kemasan ulang yang terpilih adalah sebagai berikut:

\begin{tabular}{|l|l|l|l|}
\hline Produsen & Estetika & Nuansa & Konsumen \\
\hline $\begin{array}{l}\text { Vania } \\
\text { Gabriella }\end{array}$ & Maskot & Komik & $\begin{array}{l}\text { Cocok } \\
\text { untuk anak }\end{array}$ \\
\hline $\begin{array}{l}\text { Eliyana } \\
\text { Ika } \\
\text { Widadni }\end{array}$ & Dinamis & Profesional & $\begin{array}{l}\text { Cocok } \\
\text { untuk } \\
\text { umum }\end{array}$ \\
\hline $\begin{array}{l}\text { Edric } \\
\text { Christan }\end{array}$ & Tekstur & $\begin{array}{l}\text { Fun atau } \\
\text { Asyik }\end{array}$ & \\
\hline
\end{tabular}

Teknologi Informasi dan Komunikasi 78 


\begin{tabular}{|l|l|l|l|}
\hline Produsen & Estetika & Nuansa & Konsumen \\
\hline Fachri & & & Cocok \\
Fahrezi & & & $\begin{array}{l}\text { untuk kaum } \\
\text { muda }\end{array}$ \\
\hline
\end{tabular}

Tabel 3. Daftar hasil pemilihan final desain kemasan ulang.

\section{Tahap Persiapan Display Produk}

Pada tahap ini tim penulis melakukan persiapan desain berikutnya, yaitu display produk untuk dijual pada pasar dan/atau pihak kerjasama yang akan ditentukan. Untuk itu tim penulis juga menyiapkan beberapa hal yang harus dibuat dalam membangun display produk makanan ringan Kelurahan Keranggan ini.

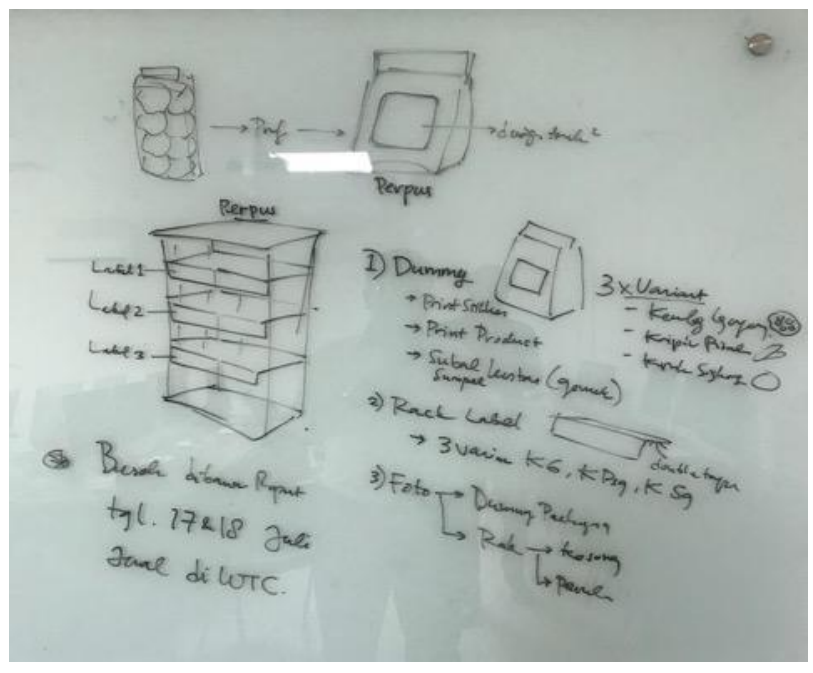

Gambar 13. Hasil diskusi tim penulis dalam persiapan jual.

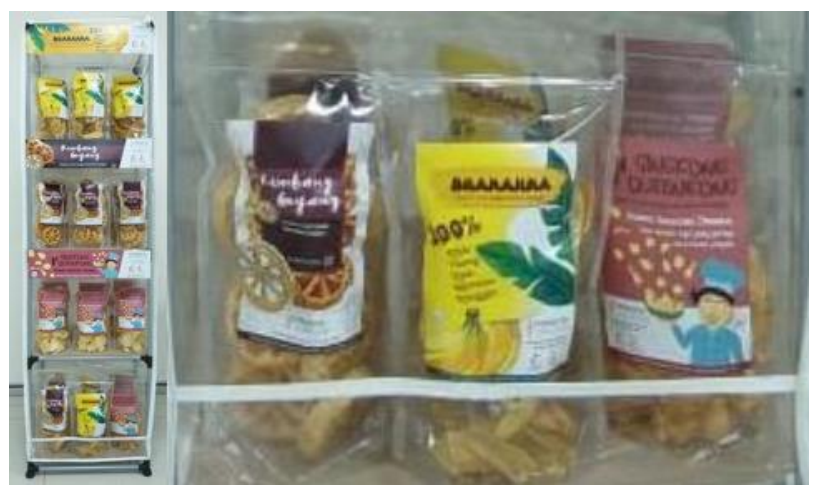

Gambar 14. Detail display produk untuk kemasan ulang.

Salah satunya adalah pertimbangan untuk menghitung harga model dengan margin yang masih laku dijual, hal ini dilakukan tim penulis dengan membuat dummy dengan skala riil sehingga terhitung jumlah modal lengkap dengan investasi rak display produk ini sendiri.

Sehingga tim penulis menyimpulkan bahwa rak untuk mendisplay ulang guna meningkatkan penjualan ini; dapat dipakai dengan baik, namun perlu ada penjagaan dari pihak penjual karena rak tidak dapat di kunci, walau dibutuhkan waktu untuk membuka atau menutup karena menggunakan resliting yang panjang.

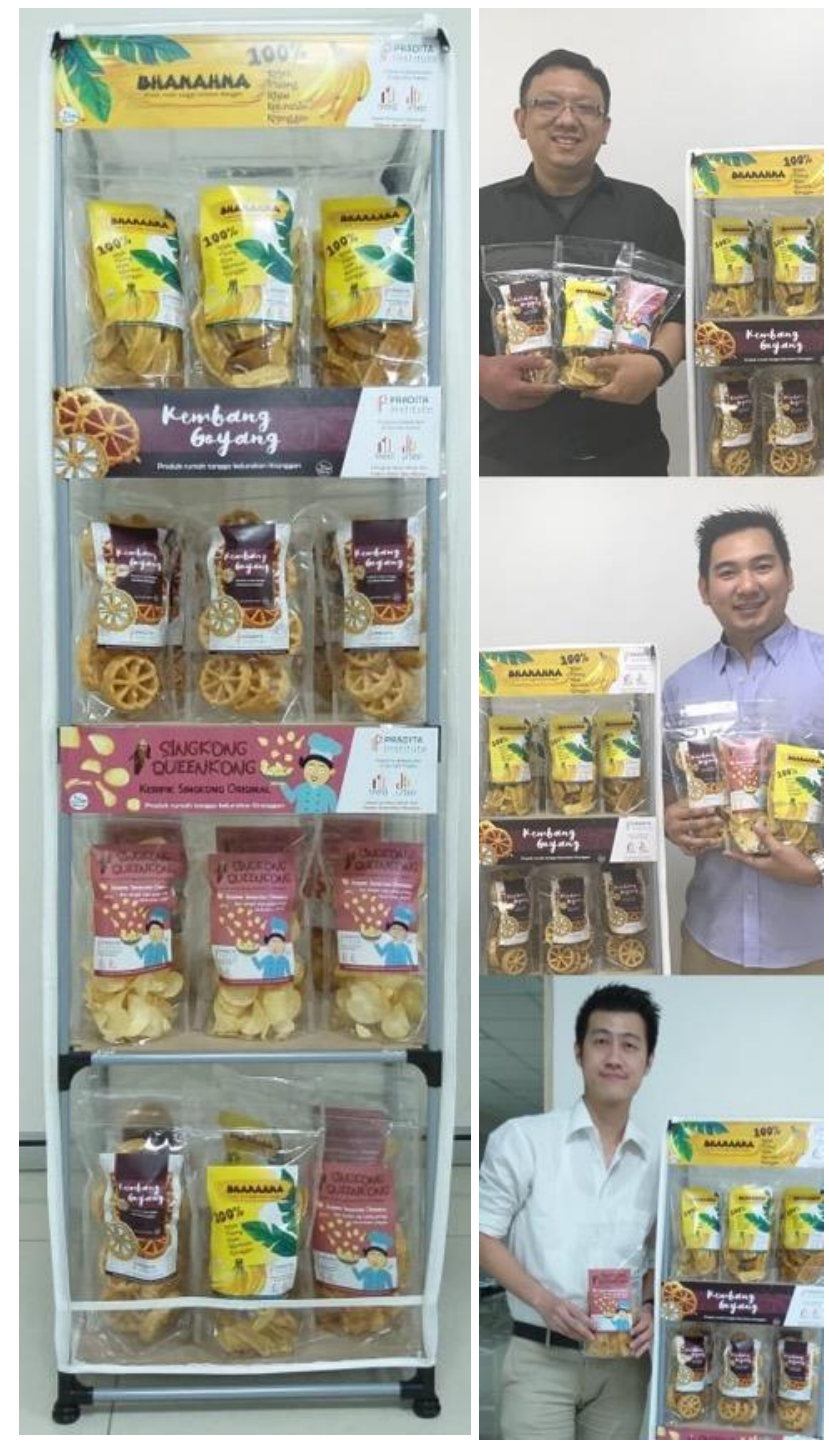

Gambar 15. Hasil display produk untuk kemasan ulang produk.

Teknologi Informasi dan Komunikasi 79 
Tahap Tes Pasar Dan Kerjasama

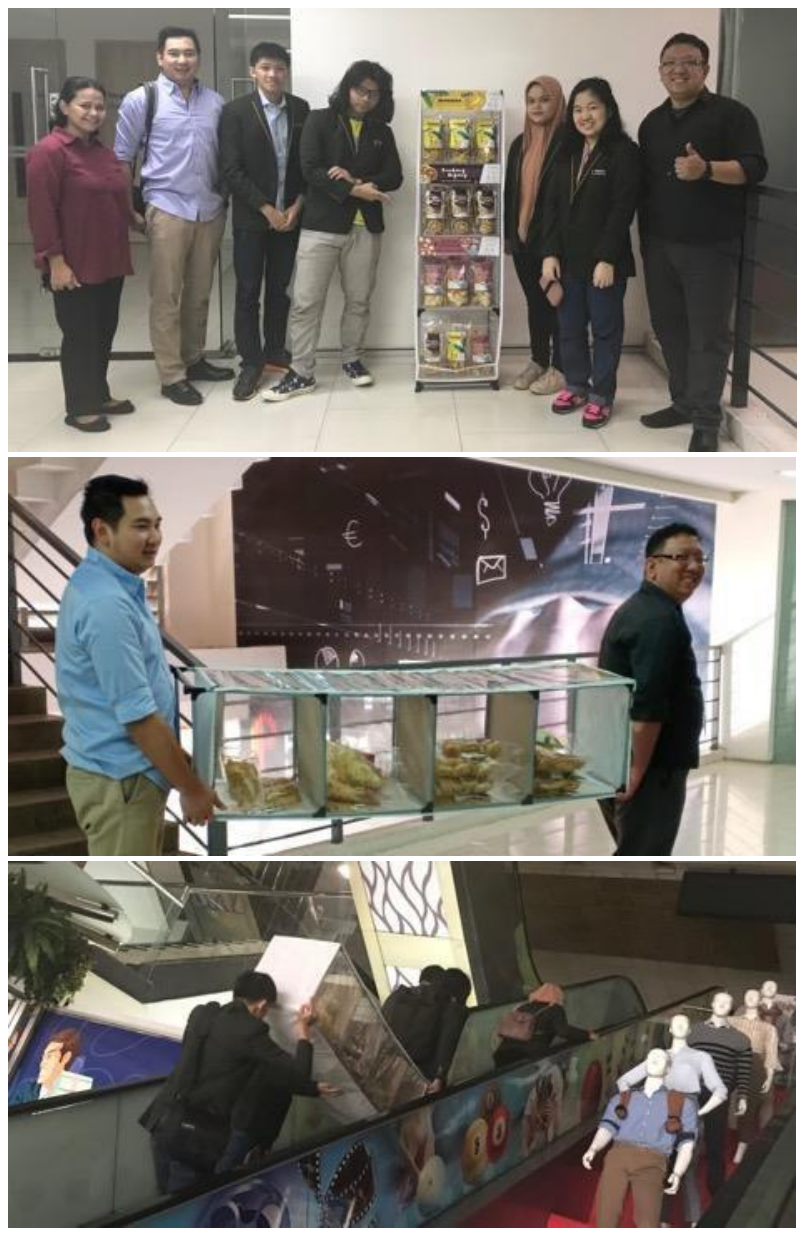

Gambar 16. Proses angkut display produk ke lokasi tes jual.

Dengan selesainya desain kemasan ulang dan display produk, tim penulis segera masuk dalam tahap kerjasama guna melakukan tes display dan jual kepada calon konsumen secara riil. Hal ini terjadi dengan membuka stand bersama dengan Akademi Bambu Nusantara (ABN) di acara pemerintah kota Tangerang Selatan yang sedang melakukan Galeri Ethnik Nusantara (Gensa). Acara ini dibuka oleh Kepala Dinas Pariwisata Kota Tangerang Selatan; Bapak Yudianto. Dia mengatakan bahwa, kehadiran Gensa merupakan solusi untuk kota Tangerang Selatan yang belum mempunyai pusat oleh-oleh. Karena disini selain pusat oleh-oleh juga ada beberapa stand kabupaten kota yang akan menjadi magnet tersendiri bagi calon konsumen manca negara ${ }^{[7]}$.

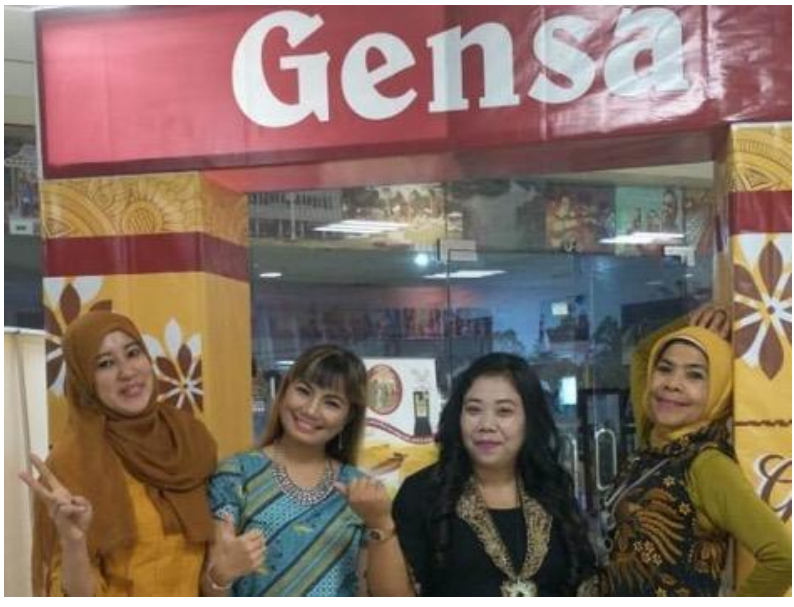

Gambar 17. Galeri Ethnik Nusantara (Gensa) untuk tes jual.

"Dalam rencana kedepan kedepannya Gensa ini mempunyai 5 program yaitu, pertama Wisata, kedua Edukasi, ketiga IT, keempat Export Impor dan kelima SDM." ungkap Direktur Utama Gensa Ibu Rachelthera Triya ${ }^{[8]}$. Walau demikian, pertimbangan tim penulis proses jual yang bersifat insidentil belum bisa menaikkan openjualan secara signifikan, hal ini terjadi karena penjualan hanya berlangsung dari hari Rabu - Minggu, tanggal 17-21 Juli 2019.

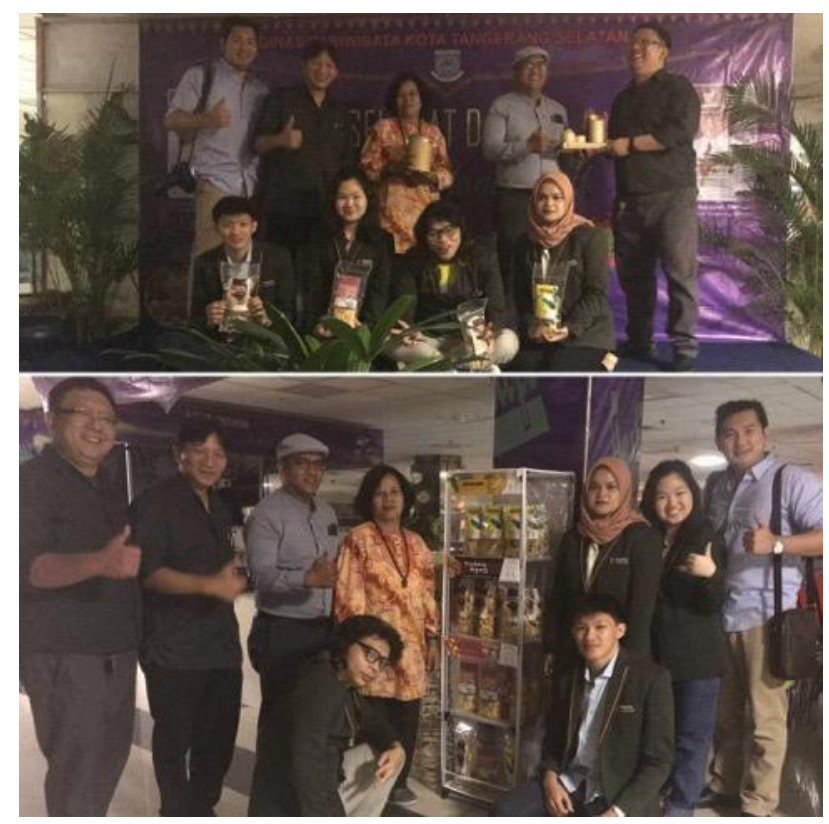

Gambar 18. Tes jual dalam Gensa bersama ABN.

Teknologi Informasi dan Komunikasi 80 
Untuk itu tim penulis kembali melakukan jalinan kerjasama lebih lanjut dengan kantin Institut Sains dan Teknologi Pradita, yang dibawah Koperasi Summarecon Grup. Dengan bertemu Bapak Cecep Suhana, dan setelah berkoordinasi dengan Bapak Antonius Hermawan selaku pengelola Koperasi Summarecon Grup, program studi Desain Komunikasi Visual mendapat izin untuk melakukan penjualan pada kantin Institut Sains dan Teknologi Pradita mulai tanggal 19 Agustus 2019. Dan hal ini akan ditelaah kembali apakah bisa dikembangkan untuk dijual ke kantin sekolah bawahan Summarecon Grup seperti Pahoa di Gading Serpong dan sekolah Al Azhar di Kelapa Gading dan Gading Serpong.

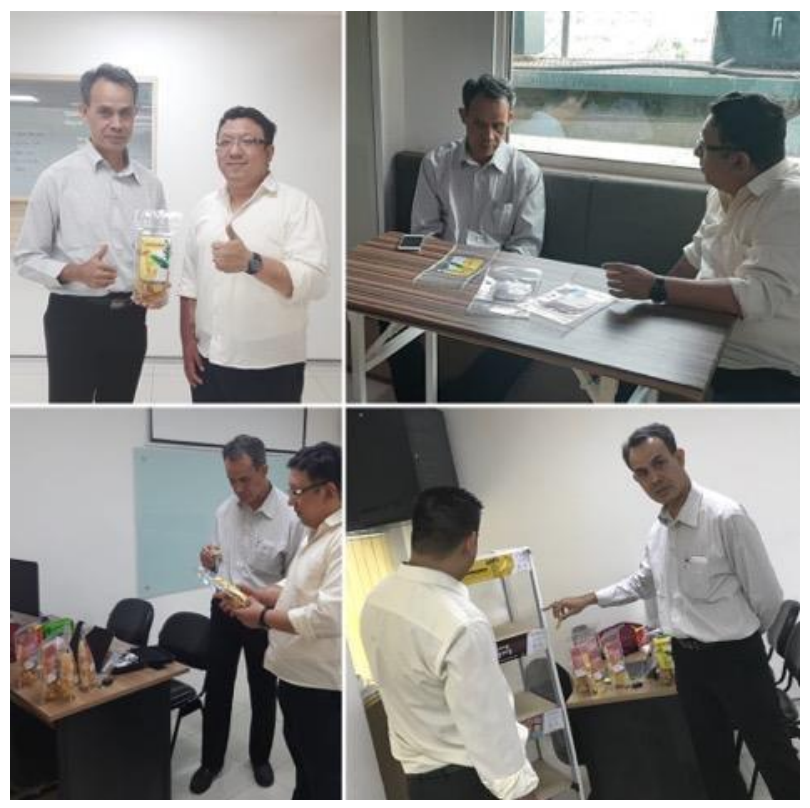

Gambar 19. Tes produk oleh Pak Cecep Suhana.

\section{KESIMPULAN}

Dari penulisan ini, tim penulis berharap terjadi manfaat untuk ketiga pihak yang terlibat; bagi Produsen kelurahan Keranggan, bagi Koperasi Summarecon, dan juga bagi pelaksana kegiatan pengabdian masyarakat ini sendiri, yaitu: Institut Sains dan Teknologi Pradita; yaitu program studi Desain Komunikasi Visual.

Untuk manfaat bagi Produsen Kelurahan Keranggan; para produsen rumah tangga, adalah: menambah pengetahuan bagi masyarakat tentang desain kemasan makanan ringan yang menarik dan sesuai dengan standard industri, dan membantu meningkatkan kualitas produk makanan ringan bagi lingkungan kelurahan Keranggan yang merupakan lingkungan permukiman dengan mayoritas masyarakatnya adalah pelaku usaha home industry.

Serta manfaat bagi Koperasi Summarecon; sebagai distributor, adalah: mendapat keuntungan dari penjualan makanan ringan untuk koperasi Summarecon, sebagai implementasi kegiatan sosial yang dilakukan koperasi untuk desa binaan, dan memberikan dampak positif bagi perekonomian masyarakat khususnya kelurahan Keranggan.

Sedangkan manfaat bagi pelaksana kegiatan pengabdian masyarakat sendiri yakni, Institut Sains dan Teknologi Pradita; program studi Desain Komunikasi Visual, adalah: memperoleh wadah untuk mengetahui kemampuan penerapan desain kemasan makanan ringan, memperoleh wadah untuk mengaplikasikan penerapan teknologi tepat guna dalam merancang desain kemasan makanan ringan untuk meningkatkan ekonomi pelaku industri rumah tangga, dan dapat berbagi dalam seminar baik dalam bentuk presentasi lisan maupun prociding tertulis guna menjadi bagian dari sharing keilmuan terapan yang mendukung perkembangan keilmuan.

\section{UCAPAN TERIMAKASIH}

Ucapan terimakasih disampaikan kepada Prof. Harianto Hardjasaputra selaku Wakil Rektor bidang Akademik; Institut Sains dan Teknologi Pradita, atas usul dan dukungan yang diberikan kepada tim penulis, tim dosen, dan seluruh mahasiswa/i dari program studi Desain Komunikasi Visual yang telah memberikan kontribusi dalam pelaksanaan kegiatan Kemasan Ulang Dan Display Produk Makanan Ringan Kelurahan Keranggan ini.

\section{REFERENSI}

[1] Noegroho, Pramita (2 Juni 2015). Hebat! \begin{tabular}{l|l} 
Teknologi Informasi dan Komunikasi & 81
\end{tabular} 
Koperasi Cipta Boga Punya Galeri Ukm Seperti Minimarket. Dikutip dari: http://bantenhits.com/2015/06/02/hebat-ko perasi-cipta-boga-punya-galeri-ukm-seper timinimarket/

[2] Fishel, Catharine. (2005). Design Secrets: Packaging. Page One Publishing, Singapore. ISBN: 981-245-240-0.

[3] Resnick, Elizabeth. (2003). Design for Communication Conceptual Graphic Design Basics. John Wiley \& Son, New Jersey. ISBN: 0-471-41829-3.

[4] Elam, Kimberly. (2004). Grid Systems. Princeton Architectural Press, New York. ISBN: 1-56898-465-0.

[5] Samara, Timothy. (2006). Type Style Finder: The Busy Designer's Guide to Choosing Type.
Page One Publishing, Singapore. ISBN: 981245-289-3.

[6] Darmawan, James. (2018). Increasing Selling Power and Brand Identity of Typical Food Snack in Kelurahan Kranggan through Packaging Design. Atlantis Press. ISBN: 97894-6252-612-9.

[7] Semarak. (2018). Hadir di Serpong, Galeri Etnik Nusantara Wadah UKM dan IKM. Dikutip dari: http://semarak.co/hadir-di-serpong-galeri-ethnik-nusantara-wadah-ukm-danikm.

[8] Citra News Indonesia. (2019). Galeri Etnik Nusantara Expo Sejuta UKM di Gelar WTC Tangsel. Dikutip dari: http://citranewsindone sia.com/2019/07/18/galeri-ethnik-nusantara-ex po-sejuta-ukm-di-gelar-wtc-tangsel.html. 